\title{
Benefits of Biochar Compost (BIOCHOM) to Yield Rice Productivity on Tropical Swampland, South Kalimantan, Indonesia
}

\author{
Wahida Annisa $^{1}$ and Evy Setiawati $^{2}$ \\ 1) Indonesian Swampland Agricultural Research Institute (ISARI), J1. Kebun Karet, Banjarbaru, South Kalimantan, Indonesia \\ ${ }^{2)}$ Institute of Research and Standardization of Industry, Ministry of Industry, Jl. Panglima Batur Barat No.2, Banjarbaru South \\ Kalimantan, Indonesia
}

\begin{abstract}
Biochar improves soil quality physicochemical. Biochar is a soil amendment created through the burning of biomass, has a potential solution for wide-ranging environmental management problems. Biochar has been shown to have positive outcomes on soil function to sequester carbon to slow the effects of global climate change. The objective of this research was to study the impact of compost biochar in increasing rice yields in tropical swampland. The design used in this study was a randomized block design, including (1) biochom 1 (without harvest waste compost + without biochar rice husk), (2) Biochom 2 (harvest waste compost $5 \mathrm{t} / \mathrm{ha}$ ), (3) biochom 3 (rice husk biochar $5 \mathrm{t} / \mathrm{ha}$ ), (4) biochom 4 (a combination of harvest waste compost $2.5 \mathrm{t} /$ ha + rice husk biochar $2.5 \mathrm{t} / \mathrm{ha}$ ). The results showed that application of biochom 4 (a combination of harvest waste compost $2.5 \mathrm{t} / \mathrm{ha}+$ rice husk biochar $2.5 \mathrm{t} / \mathrm{ha}$ ) increased of rice yield reached $15.21 \%$ compared to biochom 2 treatment (compost harvest waste $5 \mathrm{t} / \mathrm{ha}$ ) and reached $17.78 \%$ with biochom 3 treatment (rice husk biochar $5 \mathrm{t} / \mathrm{ha}$ ), compost without biochar treatment.
\end{abstract}

\section{Introduction}

Indonesia has the most abundant swampland in the tropics with sediment consisting of mineral soil, peat soils, or a combination of both. Of the total area of swampland in Indonesia, around 19.99 million ha is a potential land that can be used as agricultural land, while the remaining 14.93 million ha is not possible to be developed into agricultural land [1]. Acid sulfate soils are often found in coastal areas that are still affected by tides with high iron content, so it is very acidic [2]. The characteristic of acid sulfate soils is the presence of sulfuric horizons which generally contain large amounts of iron which causes soil $\mathrm{pH}$ to decrease to $\leq 3[3,4]$. Land under these conditions is classified into an actual acid sulfate soils with the Entisol order $[5,6]$. Sulfide minerals such as pyrite and sulfur elements resulting from the sulfur sediment reduction process are elements forming acid sulfate soils that are oxidized when pyrite is exposed to the surface due to drainage or earth movement [7].

The process of forming pyrite is influenced by several factors such as (1) the presence of soluble sulfate originating from seawater or brackish water with a concentration of $>10 \mathrm{mg} / \mathrm{L}$, (2) availability of organic matter, (3) anaerobic environment, (4) the presence of sulfate-reducing bacteria, (5) availability of active iron contained in soil sediments $[6,8]$. The sustainability of agriculture on acid sulfate soil depends on its management. One of the environmentally friendly management efforts in increasing soil productivity is utilizing local organic material. Banjar farmers have a traditional way of preparing land for rice cultivation through managing fresh organic content in anaerobic conditions (flooded) through a series of management processes known as Tajak-Puntal Balik-Hampar (trowel-puntal-turn over-spread) [9]. The existence of organic material in swampland has a function to maintain the atmosphere of reduction so that pyrite oxidation can be suppressed [10]. Microbial respiration in the soil is related to the oxidation-reduction process which affects the potential value of redox (Eh) and is an indicator of the biogeochemical process in acid sulfate soils. This potential value indicate the oxidative and reductive conditions of the land.

Biochar is a porous wood charcoal substance, often also called charcoal or agri-char because it comes from living things we call charcoal. Biochar can slowly release carbon and nitrogen and influence microbial activity, thereby improving soil properties [10]. In the soil, biochar provides suitable habitat for soil microbes such as bacteria that help in the breakdown of nutrients so that these nutrients can be absorbed by plants, but not consumed like other organic materials [11]. The addition of biochar is effective in holding back the loss of nutrients due to leaching and retention of P. Besides, biochar can also be an excellent growing medium for various soil microbes. The purpose of this study was to examine the effect of BIOCHOM (biochar compost) on rice yields in acid sulfate soil.

\section{Materials and Methods}

This research was carried out in acid sulfate soil in B type, with pyrite depth $>100 \mathrm{~cm}$ in Puntik Tengah Village, Mandastana District, Barito Kuala Regency, South Kalimantan. The condition of the water system at the study site was controlled with a one-way flow 
system. The design used in this study was a randomized block design with the following treatments:

1. Biochom 1 (without harvest waste compost + without rice husk biochar)

2. Biochom 2 (harvest waste compost $5 \mathrm{t} / \mathrm{ha}$ )

3. Biochom 3 (rice husk biochar $5 \mathrm{t} / \mathrm{ha}$ )

4. Biochom 4 (a combination of harvest waste compost $2.5 \mathrm{t} / \mathrm{ha}+$ rice husk biochar $2.5 \mathrm{t} / \mathrm{ha}$

The nursery was carried out outside the plantation business area to save time, and the seedlings were maintained between 20-25 days in the nursery. The plot size was $4 \mathrm{~m} \times 5 \mathrm{~m}$. The recommended dosage of NPK fertilizer was based on soil nutrient status. Fertilizer N (Urea) was given 3 times, at the age of 7 days after planting (HST) $1 / 3$ part, then $2 / 3$ part based on BWD (Leaf Color Chart). Whereas P (SP 36) and $\mathrm{K}(\mathrm{KCl})$ fertilizers were given at the beginning of growth. Observations were made on the chemical properties of the soil as well as the yield of dry milled unhusked rice (t GKG/ha).

\section{Results and Discussion}

\subsection{Characteristics of soil chemical properties}

Soil enrichment of carbon through the addition of biochar had a positive effect on the characteristic of acid sulfate soils. This improvement consisted of increment of soil $\mathrm{pH}$, total $\mathrm{N}$, and available $\mathrm{K}$. As a soil enhancer, biochar had durability in the soil. It could both improve the soil physicochemical properties and be a good carbon store.

Soil $p H$. Giving two types of ameliorant material increased the value of soil pH (Figure 1). Soil pH in the treatment without ameliorant also increased. The increase in $\mathrm{pH}$ in the $\mathrm{B} 1$ (control) treatment was due to the effect of submergence which makes the soil condition quite reductive, thereby encouraging the reduction of $\mathrm{Fe}^{3+}$. There was a significant negative correlation of $r=-0,856$ between the redox potential value and ferrous iron $\left(\mathrm{Fe}^{2+}\right)$ concentration [1]. Under moderate acidity conditions, $\mathrm{FeOH}$ would dissolve to $\mathrm{Fe}^{2+}$, whereas $\mathrm{Fe}^{3+}$ would be dominant in very oxidative conditions with a redox potential value $>400 \mathrm{mV}$ and $\mathrm{pH}<2$. The stable form of iron was in the form of $\mathrm{Fe}^{2+}$. However, the highest increase in the final soil $\mathrm{pH}$ value was shown in the B3 treatment (rice husk biochar 5 $\mathrm{t} / \mathrm{ha}$ ) which was reached $\mathrm{pH}$ 4.37. This was related to the role of biochar in increasing low soil $\mathrm{pH}$ values. The $\mathrm{pH}$ value of the biochar was highly dependent on the temperature of pyrolysis and the age of the biochar used [12]. The $\mathrm{pH}$ value of biochar was in the range of $\mathrm{pH} 11$ if the charcoal was still fresh (not weathered) and the temperature of pyrolysis was more than $450-500{ }^{\circ} \mathrm{C}$. If the char had been weathered and exposed during and after the pyrolysis process, the $\mathrm{pH}$ value of the charcoal would be in the $\mathrm{pH}$ range of 5-8.

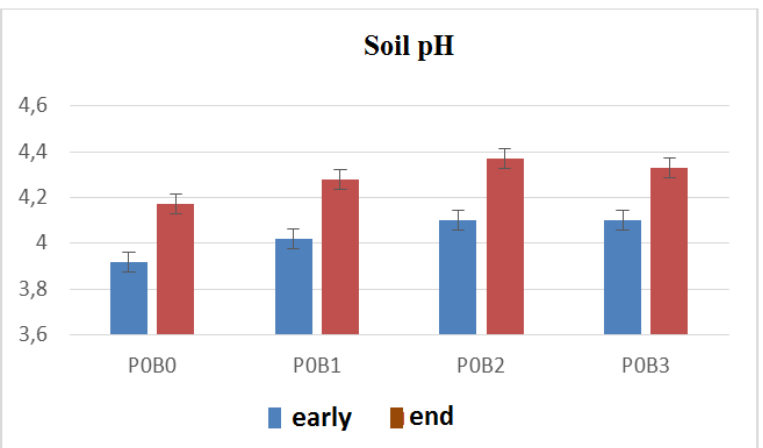

Figure 1. Changes in the soil $\mathrm{pH}$ by treatment of biochar compost ameliorant.

Total $N$ content of the soil. The total $\mathrm{N}$ content of the soil tended to increase even though it was not significantly different in the treatment of biochar and compost, except in the control treatment. The total $\mathrm{N}$ content in the control treatment decreased due to loss of $\mathrm{NO}^{3-}$ after several days of flooding due to the denitrification process. It could produce nitrogen gas $\left(\mathrm{N}_{2}\right)$, which reduced nitrates due to the reduced redox potential of the soil. The decreased in total $\mathrm{N}$ content of the soil would be followed by an increase in $\mathrm{Fe}^{2+}$ soil concentration. An increase in total $\mathrm{N}$ content of the soil was seen in B2 treatment because the addition of highquality organic material would encourage an intensive ammonification process. It was supported by highly reductive soil conditions (low redox potential of the soil) which would increase the availability of $\mathrm{NH}^{4+}$.

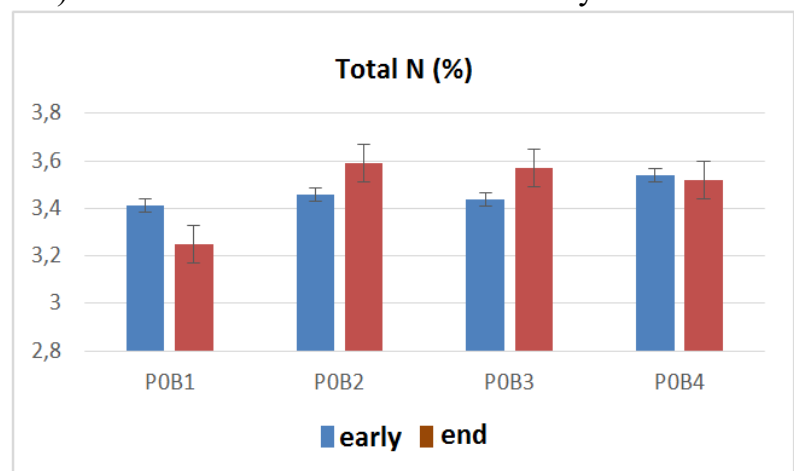

Figure 2. Changes in the soil total $\mathrm{N}$ content by treatment of biochar compost ameliorant

Available $K$ content. Biochar addition as ameliorant increased the available $\mathrm{K}$ content in acid sulfate soils. This was related to the role of biochar in nutrient retention compared to compost or other organic materials. Biochar was more persistent in the land than other organic materials, so all the benefits associated with nutrient retention and soil fertility could run longer than other forms of organic matter that were normally given. Potassium, K, could be lost through washing or lost with drainage water. The presence of biochar in swamplands could retain K nutrients so that they would not be able to disappear with drainage water. 


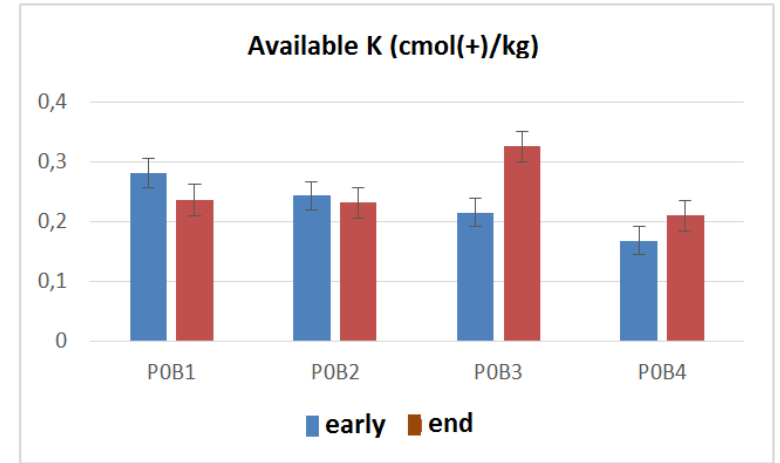

Figure 3. Changes in the soil available $\mathrm{K}$ content by treatment of biochar compost ameliorant

\subsection{Plant growth}

The highest plant height was shown in B2 treatment which reached $118.5 \mathrm{~cm}$ followed by B3 treatment of $116 \mathrm{~cm}$ (Figure 4). This was because the addition of compost and biochar ameliorant would increase nutrient $\mathrm{N}$ (Figure 2). The most crucial role of $\mathrm{N}$ elements in plants was as a constituent or as an essential ingredient of protein and the formation of chlorophyll. Hence $\mathrm{N}$ had the function of making plant parts became greener which contained a lot of green grains, accelerated plant growth, and increased plant height and number of tillers (Figure 5). Besides, $\mathrm{N}$ could increase leaf and grain size, improve crop and grain quality, increase rice protein content and percentage of filled grain content, provide food for microbes (microorganisms which work to destroy organic material in the soil) [13].

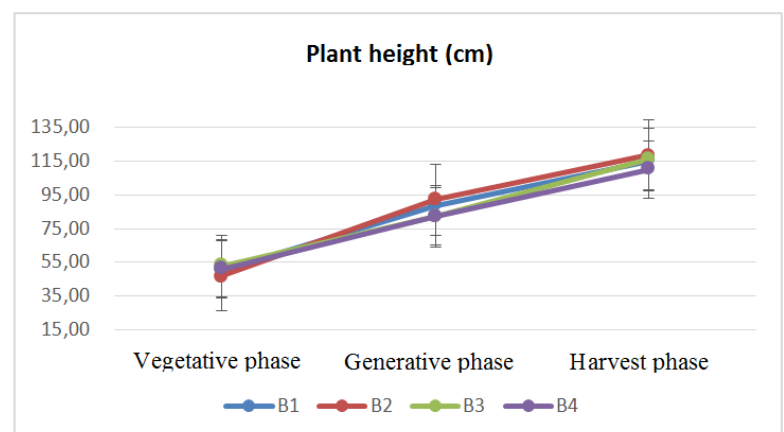

Figure 4. Rice plant height by treatment of biochar compost ameliorant.

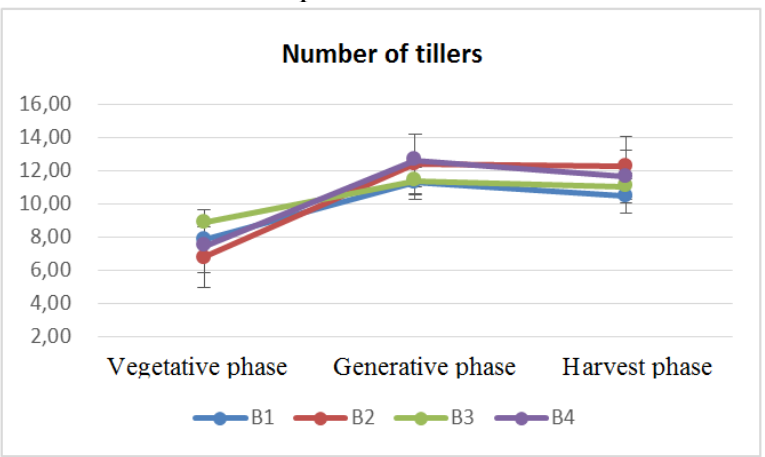

Figure 5. Number of tillers by treatment of biochar compost ameliorant.

\subsection{Rice yield}

The highest grain yield was shown in the B4 treatment, which reached $3.71 \mathrm{t} / \mathrm{ha}$, and the lowest was demonstrated in the B1 treatment (control), which only reached $1.85 \mathrm{t} / \mathrm{ha}$. This was because the biochar and compost addition was able to increase nutrient content. The use of nutrients was also optimal because the process of releasing the nutrients was slowly. The nutrient elements which had an essential role in the growth and production of rice plants were $\mathrm{N}, \mathrm{P}$, and $\mathrm{K}$ [14]. The content of $\mathrm{N}$ in urea fertilizer $\mathrm{CO}\left(\mathrm{NH}_{2}\right)_{2}$ was $46 \%$. Urea could be directly utilized by plants, but generally in the soil would be converted into ammonium and nitrate through the process of ammonification and nitrification by soil bacteria.

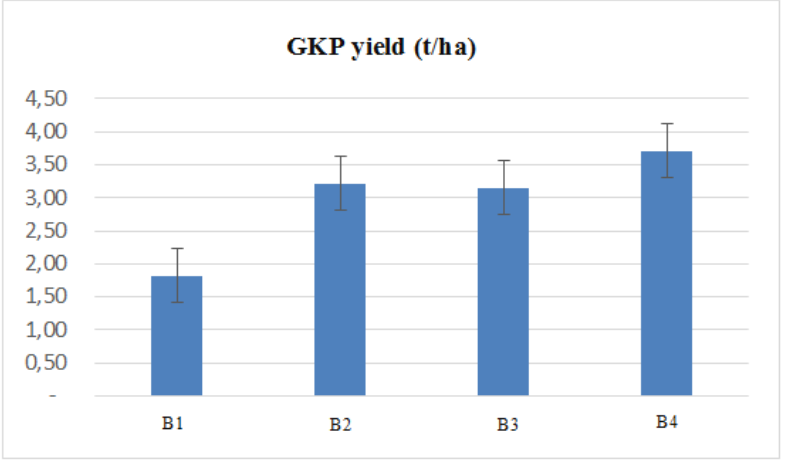

Figure 6. Rice yield by treatment of biochar compost ameliorant.

\section{Conclusions}

Biochar compost treatment could improve the acid sulfate soil physicochemical properties and rice growth. The combination of biochar compost treatment gave the highest dry grain yield reaching $103.8 \%$ compared to compost treatment only increased grain yield by $76.9 \%$ compared to control treatments (without biochar and compost).

\section{References}

1. Annisa W and Nursyamsi D Indonesian Soil and Climate J. 40135 (2016)

2. Annisa W and Maas A 2015 J. Trop. Soils 20135 (2015)

3. Muhrizal S, Shamshuddin J, Fauziah and Husni M A H Geoderma 131110 (2006)

4. Natural Resources Conservation Service. Use of reaction $(p H)$ in soil taxonomy (United States: Departement of Agriculture) (2010)

5. Andriesse W. Acid sulphate soil: diagnosing the illness, ed D L Dent and M E F Van Mensvoort (Wageningen: ILRI) pp 11-29 (1993) 
6. Fitzpatrick R W, Merry R H, Williams J, White I, Bowman G and Taylor G. Methods Paper 18 (1998)

7. Janjirawutikul $\mathrm{N}$, Umitsu $\mathrm{M}$ and Towernpruek $\mathrm{S}$. Int. J. of Soil Sci. 677 (2011)

8. Rabenhorst et al. Acid Sulfate Soils In: Encyclopedia of Soil Science, ed R Lal (New York: Marcel Dekker Inc.) pp 14-17. (2002)

9. Annisa W, Cahyana D, Syahbuddin H and Rachman A. Proc. Materials Science and Engineering 209012089 (2017)

10. Annisa W and Nursyamsi D. Indonesian J. of Agr. Sci. 171 (2017)
11. Karhu K, Mattila T, Bergstrom I and Regina K Agr. Ecosyst. Environ. 140309 (2011)

12. Ammonette J E. Biochar introduction http:// www.slideshare.net/NSCSS/

ammonettebiocharintroduction (2010)

13. Dobermann A and Fairhust T. Rice : Nutrient Disorders and Nutrient Management (Philipine: IRRI) pp.191 (2000)

14. Leiwakabessy FM and Sutandi A. Pupuk dan pemupukan (Bogor: Fakultas Pertanian-IPB) (2004) 